Research Article

\title{
Formulation and Evaluation of Sustained Release Matrix Tablets of Aceclofenac
}

Priyanka Singh 10
Amit Kumar Shrivastava 2*0
Sachin Kumar ${ }^{*}$
Manish Dhar Dwivedi 10
'Department of Pharmacy, Sardar Patel
College of Pharmacy, Gorakhpur, Uttar
Pradesh, India
'Department of Pharmacology,
Universal College of Medical Sciences,
Siddharthanagar, Lumbini Pradesh,
Nepal Pharmacy, NKBR
3Department of Pharch
College of Pharmacy and Research
Centre, Meerut, Uttar Pradesh, India
*email: sr.akshri.ucms.np@gmail.com
Keywords:
Aceclofenac
Controlled release tablet
Sustained release matrix tablet

\begin{abstract}
This study aimed to improve the dissolution rate of aceclofenac and release the drug in a controlled manner over a period of 24 hours. Matrix tablets were prepared by direct compression method, using hydrophilic polymers (HPMC/guar gum). Matrix tablets were prepared by wet granulation method using different hydrophilic polymers (HPMC/guar gum). Tablets were evaluated for in vitro drug release profile in phosphate buffer with $\mathrm{pH} 6.8$ (without enzymes). The thickness and hardness of prepared tablets were $3.23 \pm 0.035$ to $3.28 \pm$ $0.008 \mathrm{~mm}$ and $3.26 \pm 0.115$ to $3.60 \pm 0.200 \mathrm{~kg} / \mathrm{cm} 2$, respectively. The friability was within the acceptable limits of pharmacopoeial specifications (0.31 to $0.71 \%$ ), which indicates the good mechanical strength of the tablets. Drug release was retarded with an increase in polymer concentration due to the gelling property of polymers. The in vitro drug release from the proposed system was best explained by Higuchi's model, indicating that drug release from tablets displayed a diffusion-controlled mechanism. The results clearly indicate that guar gum could be a potential hydrophilic carrier in developing oral controlled drug delivery systems. Based on the study results, formulations F8 was selected as the best formulation.
\end{abstract}

Received: November 29th, 2020

Accepted: February 19th, 2021

Published: May 30th, 2021

(c) 2021 Priyanka Singh, Amit Kumar Shrivastava, Sachin Kumar, Manish Dhar Dwivedi. Published by Institute for Research and Community Services Universitas Muhammadiyah Palangkaraya. This is an Open Access article under the CC-BY-SA License (http://creativecommons.org/licenses/by-sa/4.0/). DOI: https:// doi.org/10.33084/bjop.v4i2.1854

\section{INTRODUCTION}

Oral drug delivery is the most widely applicable administration route among all other drug administration routes such as nasal, ophthalmic, rectal, transdermal, and parenteral routes. It has been explored for systemic delivery of drugs via pharmaceutical products of a different dosage form ${ }^{1}$. The majority of the pharmaceutical products designed for oral delivery are immediate release or conventional release systems for rapid drug absorption ${ }^{2}$. Conventional dosage forms have various limitations to deliver the dosage form via the oral route, such as poor patient compliance, increased chances of dose missing of a drug with a short half-life for which frequent administration is necessary ${ }^{3}$.

In order to overcome the drawbacks of conventional drug delivery systems, several technical advancements have led to the development of a controlled drug delivery system that could revolutionize the method of medication and provide several therapeutic benefits ${ }^{4}$. Controlled drug delivery systems have been developed to control the rate of drug delivery, sustaining the duration of therapeutic activity and targeting the delivery of drugs to tissues ${ }^{5}$. Controlled drug delivery or modified drug delivery systems are conveniently divided into four 
categories: delayed release, sustained release, site-specific targeting, and receptor targeting ${ }^{6}$.

A controlled drug delivery system is usually designed to deliver the drug at a particular rate. Safe and adequate blood levels are maintained for a period as long as the system continues to deliver the drug7. Controlled drug delivery usually results in substantially constant blood levels of the active ingredient compared to the uncontrolled fluctuations observed when multiple doses of quick releasing conventional dosage forms are administered to a patient ${ }^{8}$.

The introduction of matrix tablets as the sustained release (SR) has given a breakthrough for novel drug delivery systems (NDDS) in pharmaceutical technology ${ }^{9}$. It excludes complex production procedures such as coating and palletization during manufacturing, and the drug release rate from the dosage form is controlled mainly by the type and proportion of polymer used in the preparations ${ }^{10}$. The hydrophilic polymer matrix is widely used for formulating an SR dosage form. Because of increased complications and expense involved in the marketing of new drug entities, it has focused greater attention on developing sustained release or controlled release drug delivery systems ${ }^{11}$.

Matrix systems are widely used for sustained release. It is the release system that prolongs and controls the release of the dissolved or dispersed drugs ${ }^{12}$. A matrix is a wellmixed mixture of one or more drugs and a gelling agent, such as hydrophilic polymers. The sustained release approach allows for therapeutically efficient accumulation in the systemic circulation over a more extended period, resulting in improved patient compliance $^{13}$.

Many SR oral dosage forms have been developed, including membrane-controlled systems, matrix with water-soluble/insoluble polymers or waxes, and osmotic systems. Recent research has concentrated on the designation of SR systems for poorly water-soluble drugs $^{14}$. The lipid waxes and related materials prepare the lipid matrix. In this system, the active compound is contained in a hydrophobic matrix that remains intact during drug release ${ }^{15}$.

The release of the active substance depends on the aqueous medium dissolving the conduit, which is released from the solids, forming a porous matrix of tortuous capillaries. The active substance dissolves in the aqueous medium and diffuses out of the matrix by way of the water-filled capillaries ${ }^{16}$. The materials used as matrix formers include hydrogenated vegetable oil, hydrogenated cottonseed oil, hydrogenated soy oil, microcrystalline wax, carnauba wax, as well as hydroxypropyl methylcellulose (HPMC) ${ }^{17}$.

Aceclofenac is a potent inhibitor of the enzyme cyclooxygenase, which is involved in the production of prostaglandins ${ }^{18}$. The drugs inhibit the synthesis of the inflammatory cytokines interleukin (IL)-1 and tumor necrosis factor (TNF) and prostaglandin E2 (PGE2) production. Effects on cell adhesion molecular from neutrophils have also been noted. In vitro data indicate inhibition of cyclooxygenase (COX)- 1 and 2 by aceclofenac in whole blood assays, with selectivity for COX-2 being evident ${ }^{19}$.

Aceclofenac is a perfect applicant for a sustained release tablet. It reduces the frequency of drug administration and improves bioavailability, and increases patient compliance $^{20}$. Aceclofenac has a short biological half-life of 2-4 hours; thus, it does not show the pharmacological effect for a long time ${ }^{21}$. Sustained-release tablets have the properties to release slowly, and they maintain the bioavailability of drugs for a long time. Therefore, in this study, we made a sustained release tablet of aceclofenac and determined all in vitro parameters of sustainedrelease tablets. 


\section{MATERIALS AND METHODS}

\section{Materials}

The material used were aceclofenac (Sigma-Aldrich), HPMC K15M, Guar gum, lactose, polyvinylpyrrolidone (PVP) K-30, isopropyl alcohol (IPA), talc, magnesium stearate, phosphate buffer $\mathrm{pH} 6.8, \mathrm{HCl}$, distilled water, and $\mathrm{KBr}$. The instruments used include melting point apparatus, water bath shaker, UV spectrophotometer (Labindia), Fourier Transform Infrared (FTIR) Spectroscopy (Shimadzu), sieve \#10, \#18, \#40, digital analytical balance, micromeritics instrument, micrometer (Mitutoyo), Monsanto tablet hardness tester, Roche friabilator, and dissolution apparatus type 1 basket.

\section{Methods}

The study was divided into three stages: preformulation, granule preparation-evaluation, and tablet formulationevaluation. Each stage consists of several tests and evaluations. The method flow chart is presented in Figure 1.

\footnotetext{
1. Physical appearance

\section{Preformulation}

2. Melting point

3. Solubility studies

4. Compatibility study of drug and polymer (FTIR)
}

\begin{tabular}{|l|}
\hline \multicolumn{1}{|c|}{ Granule preparation } \\
1.
\end{tabular}

\begin{tabular}{|ll|}
\hline \multicolumn{1}{|c|}{ Tablet formulation } \\
1. & Examination of tablet appearance \\
2. & Determination of tablet thickness \\
3. & Determination of uniformity of weight \\
4. & Determination of tablet hardness \\
5. & Determination of tablet friability \\
6. & Determination of drug content \\
7. & Determination of in vitro dissolution profile \\
\hline
\end{tabular}

Figure 1. Flowchart for sustained release tablet preparation and evaluation parameters

\section{Physical appearance}

Aceclofenac powder was poured on light and dark backgrounds, and its physical appearance was observed. The results were compared with standard references ${ }^{22}$.

\section{Determination of melting point}

The melting point of the aceclofenac was determined by the capillary fusion method. A one-sided closed capillary was filled with drug and placed into the Remi's melting point apparatus. The temperature at which solid drug converted into liquid was recorded and compared with standard references 22 .

\section{Solubility studies}

The solubility of Aceclofenac was tested in different solvents. The drug (50 mg) was dissolved in $10 \mathrm{ml}$ of solvent in a $10 \mathrm{~mL}$ solubility bottle. The bottle was adequately covered with a lid and placed in the water bath shaker maintained at $37^{\circ} \mathrm{C}$ for 24 hours. Samples were taken manually and filter through $0.45 \mu \mathrm{m}$ filter paper. The UV absorbance of the solution was recorded using a UV spectrophotometer after suitable dilutions at $273.5 \mathrm{~nm}^{23}$.

\section{Compatibility study of drug and polymer (FTIR)}

The sample was mixed with a suitable amount of $\mathrm{KBr}$ and converted into pellets using $\mathrm{KBr}$ press at 15 tons hydraulic pressure. The IR scanning of samples was done in between 4000 and $400 \mathrm{~cm}^{-1}$ and spectrum observed for any occurrence and disappearance of characteristic drug peak and compared with the standard references ${ }^{23}$.

\section{Tablet preparation}

The tablet formulation was carried out by varying the matrix formers: HPMC and Guar gum. In total, there were nine formulas for tablets, as shown in Table I. The corresponding amounts of the drug were accurately weighed and passed through the \#40 sieve. The corresponding amounts of polymers (HPMC/Guar gum) and lactose were accurately weighed, screened 
through screen \#40. The screened mass was transferred into a clean and dry mortar and mixed gently for 5 minutes. Alcoholic solution (IPA) of PVP K 30 (5\% w/v) was added to the powder mixture blended to form a wet mass. The wet mass was passed through sieve no. \#10 and the resulting granules were placed on a tray for drying into the oven at $50^{\circ} \mathrm{C}$ for 10 minutes. The dried granules were passed through sieve no-\#18. The corresponding magnesium stearate and talc were accurately weighed and then mixed with dried granules for 3 minutes. The granules were compressed into tablets using a single station hand operated tablet compression machine, and the tablets were collected ${ }^{23}$.

Table I. Composition of the sustained release matrix tablets containing aceclofenac

\begin{tabular}{lccccccccc}
\hline \begin{tabular}{c} 
Materials \\
\multicolumn{1}{c}{$(\mathbf{m g})$}
\end{tabular} & \multicolumn{10}{c}{ F1 } & F2 & F3 & F4 & F5 & F6 & F7 & F8 & F9 \\
\hline Aceclofenac & 200 & 200 & 200 & 200 & 200 & 200 & 200 & 200 & 200 \\
HPMC & 50 & 100 & 150 & 200 & - & - & - & - & 100 \\
Guar gum & - & - & - & - & 50 & 100 & 150 & 200 & 100 \\
Lactose & 200 & 150 & 100 & 50 & 200 & 150 & 100 & 50 & 50 \\
PVP K30 & 25 & 25 & 25 & 25 & 25 & 25 & 25 & 25 & 25 \\
IPA & q.S. & q.s. & q.s. & q.s. & q.s. & q.s. & q.s. & q.s. & q.s. \\
Talc & 20 & 20 & 20 & 20 & 20 & 20 & 20 & 20 & 20 \\
Mg Stearate & 5 & 5 & 5 & 5 & 5 & 5 & 5 & 5 & 5 \\
\hline
\end{tabular}

\section{Determination of bulk density}

Bulk density was defined as the mass of the powder divided by the bulk volume and expressed as $\mathrm{g} / \mathrm{cm}^{3}$. It depends upon particle size distribution, particle shape, and particle adhere. Apparent bulk density was determined by pouring the blend into a $10 \mathrm{~mL}$ graduated cylinder and calculated based on the equation as reported by Yasmin et al24.

\section{Determination of tapped density}

The measuring cylinder containing a known mass of powder blend was tapped 100 times using density apparatus. The minimum volume occupied by the powder in the cylinder was measured. The tapped density was calculated based on the equation as reported by Yasmin et al24.

\section{Determination of angle of repose}

The angle of repose $(\theta)$ was determined using the funnel method. Briefly, the powder blend was poured through a funnel that can be raised vertically until a maximum cone height was obtained. The radius of the heap was measured, and the angle of repose was calculated based on the equation as reported by Yasmin et $a^{24}$. The values of angle of repose indicating flow properties have been recommended as <25 indicating excellent flow, 25-30 indicating good flow, 30-40 indicating passable, and >40 indicated the very poor flow.

\section{Determination of compressibility index}

Determination of compressibility index was the simplest way to measure the flow property of powder to determine its compressibility. Compressibility index indicates the ease with which a material could induce flow, which was calculated using the equation as reported by Yasmin et $a^{24}$. The values of compressibility index indicating flow properties have been recommended as <12 indicating excellent flow, 12 - 16 indicating good flow, 18 - 21 indicating fair to passable, 25 - 35 indicating poor, 33 - 38 indicating very poor, and $>40$ indicated the extremely poor flow.

\section{Determination of Hausner's ratio}

Hausner's ratio was an indirect index of ease of powder flow. Density determinations were used to calculate the Hausner's ratio using the equation as reported by Yasmin et $a^{24}$. Lower Hausner's ratio $(<1.25)$ indicates better flow properties than higher ones $(>1.25)$.

\section{Examination of tablet appearance}

Twenty tablets of each formulation were randomly taken and examined to check any physical or surface roughness in the tablets.

\section{Determination of tablet thickness}

Tablet thickness was an essential parameter in reproducing appearance and also in counting by suing 
filling equipment. Many tablet filling/packaging equipment utilizes the uniform thickness of the tablets as a counting mechanism ${ }^{25}$. In the present study, 10 tablets were randomly selected, and their thickness was recorded using a micrometer.

\section{Determination of uniformity of weight}

The weight variation test would be a satisfactory method of determining the drug content uniformity. USP procedure for uniformity of weight was followed. The allowed weight variation limits were $10 \%, 7.5 \%$, and $5 \%$ for tablets having weight $130 \mathrm{mg}$ or less, $130-324 \mathrm{mg}$, and $>324 \mathrm{mg}$, respectively ${ }^{26}$. Briefly, 20 tablets were taken and weighed individually and collectively using a digital analytical balance. The average weight of one tablet was determined from the collective weight.

\section{Determination of tablet hardness}

The hardness of the tablet was defined as the force applied across the diameter of the tablet to break it. The resistance of a tablet to chipping, abrasion, or breakage under the condition of storage, transportation, and handling before use depends on its hardness or strength $^{27}$. For the determination of tablet hardness, 10 tablets from each batch were randomly selected, and hardness was determined using Monsanto tablet hardness tester.

\section{Determination of tablet friability}

The friability of the prepared tablets was determined using Roche friabilator. This device subjects the tablets to the combined effect of abrasions and shock in a plastic chamber revolving at $25 \mathrm{rpm}$ and dropping the tablets at the height of 6 inches in each revolution. Previously weighed, 20 tablets were placed in the friabilator and subjected to 100 revolutions. Tablets were de-dusted using a soft muslin cloth and re-weighed. The percentage friability was determined using the equation as reported by Ahmed et al28.

\section{Determination of drug content}

Six tablets from each batch were weighed and finely powdered using a clean and dry mortar and pestle. Powder equivalent to the weight of one tablet was transferred to a $100 \mathrm{~mL}$ volumetric flask and shaken with $60 \mathrm{~mL}$ of phosphate buffer for 10 minutes. The volume of the resulting solution was made to $100 \mathrm{~mL}$ and kept for 24 hours. After 24 hours, the content was filtered. An aliquot of $1.0 \mathrm{~mL}$ from the filtrate was diluted to $100 \mathrm{~mL}$ with phosphate buffer in a volumetric flask, and then further $1 \mathrm{~mL}$ from this solution was diluted up to $10 \mathrm{~mL}$ phosphate buffer in a $10 \mathrm{~mL}$ volumetric flask ${ }^{29}$. The sample was analyzed by a UV spectrophotometer at $273.5 \mathrm{~nm}$.

\section{Determination of in vitro dissolution profile}

The in vitro dissolution studies were carried out in the USP tablet dissolution test apparatus, type 1 (basket). As much as $900 \mathrm{~mL}$ of phosphate buffer (without enzymes) was used as a dissolution medium. Dissolution studies were carried out for 24 hours. The temperature of the dissolution medium was maintained at $37 \pm 0.5^{\circ} \mathrm{C}$. The paddle was rotated at $75 \mathrm{rpm}$. Sample $(5 \mathrm{~mL})$ was withdrawn data predetermined interval for 24 hours. Complete sink condition was maintained by replacing the same volume of fresh dissolution medium after each sampling. The samples were diluted to a suitable volume with phosphate buffer, and the absorbance was recorded at $273.5 \mathrm{~nm}$ using a UV spectrophotometer ${ }^{23}$.

\section{RESULTS AND DISCUSSION}

\section{Physical appearance}

Pure aceclofenac used in the form of a faded white crystalline powder as stated in the physical identification results of the drug sample was identical to the reference standard. These results confirm the identity of aceclofenac. 


\section{Determination of melting point}

The melting point value observed was $149^{\circ} \mathrm{C}$. These values match the values mentioned in standard references $\left(149-153^{\circ} \mathrm{C}\right)^{22}$, confirming that the drugs used in this study were in their pure form.

\section{Solubility studies}

Aceclofenac has better solubility in phosphate buffer and does not have good solubility in distilled water and $0.1 \mathrm{~N}$ $\mathrm{HCl}$, as presented in Table II.

Table II. Solubility of aceclofenac

\begin{tabular}{|c|c|c|}
\hline Solvent & Solubility $(\mathrm{mg} / \mathrm{mL})$ & Remark \\
\hline Distilled water & 0.187 & $\begin{array}{l}\text { practically } \\
\text { insoluble }\end{array}$ \\
\hline $0.1 \mathrm{~N} \mathrm{HCl}$ & 0.283 & $\begin{array}{l}\text { practically } \\
\text { insoluble }\end{array}$ \\
\hline Phosphate buffer & 0.841 & $\begin{array}{l}\text { slightly } \\
\text { soluble }\end{array}$ \\
\hline
\end{tabular}

\section{Compatibility study of drug and polymer (FTIR)}

The peaks at $3319 \mathrm{~cm}^{-1}$ and $3267 \mathrm{~cm}^{-1}$ in the FTIR spectrum of aceclofenac (Figure 2) are associated with $\mathrm{OH}$ hydrogen bonds. This peak at $2970 \mathrm{~cm}^{-1}$ was due to the aromatic stretching of NH. The stick peak character near $2937 \mathrm{~cm}^{-1}$ may be due to the stretching of the $\mathrm{CH}$ from the $\mathrm{CH}$ groups. The peak at $1750 \mathrm{~cm}^{-1}$ indicates the presence of carboxylic acids in the compound. The peaks at $1589 \mathrm{~cm}^{-1}, 1577 \mathrm{~cm}^{-1}$, and $1508 \mathrm{~cm}^{-1}$ indicate a stretch of the $\mathrm{C}=\mathrm{C}$ ring. The overall functional group analysis is presented in Table III.

Table III. FTIR spectrum of aceclofenac and its functional groups

\begin{tabular}{cl}
\hline Peak $\left(\mathbf{c m}^{-1}\right)$ & \multicolumn{1}{c}{ Remark } \\
\hline 3319 & OH hydrogen bonding \\
3267 & OH hydrogen bonding \\
2970 & NH aromatic stretching \\
2937 & CH stretching \\
1750 & C=O stretching \\
1589 & C $=$ C stretching \\
1577 & C $=$ C stretching \\
1508 & C $=$ C stretching \\
\hline
\end{tabular}

\section{Micromeritic properties}

The flow property of granules was estimated based on different micromeritic properties. The bulk density and tapped density were determined using USP bulk density apparatus, and the results are represented in Table IV. The bulk density and tapped density were found to be almost similar, indicating similar flow properties. The differences in bulk density and tapped density were minimal, indicating that the change volume is significantly less even after 100 tapping ${ }^{30}$, which confirms uniform particle size range and reproducibility in drug. Hausner's ratio is related to inter-particle friction. Hausner's ratio is indirect measures of bulk density, size, and shape, surface area, moisture content, and cohesiveness of granules. A higher Hausner's ratio and more fine particles indicate greater cohesion between particles, while a low range of Hausner's ratio indicates good flowability. The desirable value of Hausner's ratio is $<1.25$ for a good flow of materials. The Hausner's ratio of granules was determined and found to be in the range of $1.12 \pm 0.040$ to $1.19 \pm 0.035$. An increase in Hausner's ratio is due to an increase in granule size, and this might be due to increased void space between the particles ${ }^{31}$.

It is well known that particle size and shape influence flowability. The fine particles $(<100 \mathrm{~mm})$ tend to be more cohesive and therefore less free-flowing, whereas larger denser particles tend to be free-flowing. The rougher and more irregular the surface of the particles, the higher will be the angle of repose ${ }^{32}$. In the present study, the angle of repose increased from $26.78 \pm 0.600$ to $30.60 \pm 0.566^{\circ}$ as the particle size increased, indicating the decrease in flowability of granules ${ }^{33}$. This is also supported by the results of Hausner's ratio study.

A high compressibility index is indicative of the tendency to form bridges between the particles. The smaller the compressibility index, the better the flow properties; for example, a value of 5 to 15 indicates excellent, 12 to 18 good, 19 to 21 fair and 22 to 35 poor, 36 to 40 very poor, and $>40$ extremely poor flow ${ }^{34}$. The results show a compressibility index in the range of $10.93 \pm 0.150$ to $14.76 \pm 0.462$, which indicates excellent flow property. 


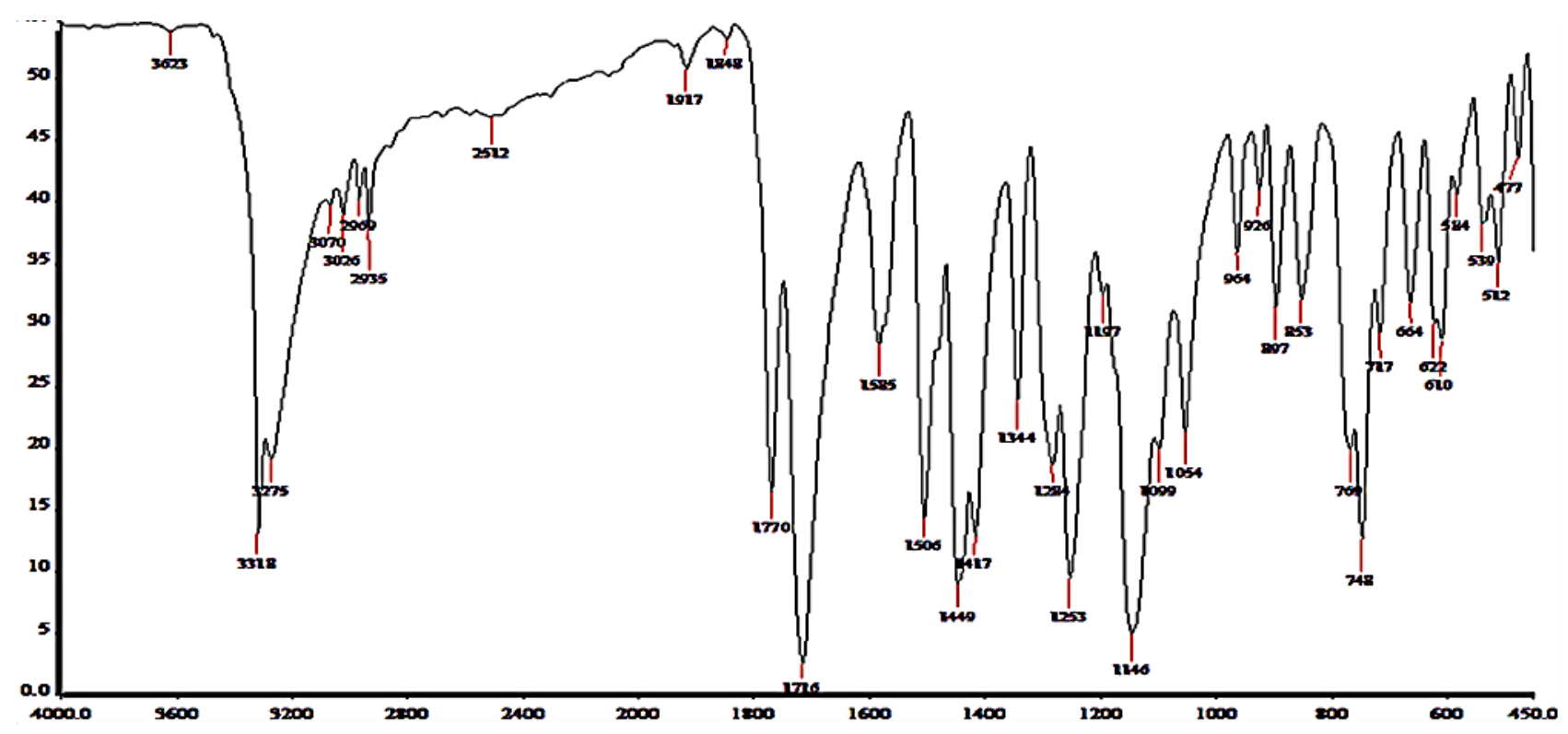

Figure 2. FTIR spectrum of aceclofenac

Table IV. Results of micromeritic characterization of aceclofenac granules

\begin{tabular}{|c|c|c|c|c|c|}
\hline 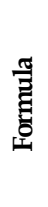 & 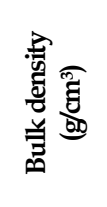 & 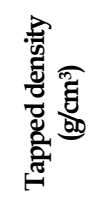 & 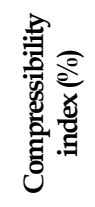 & 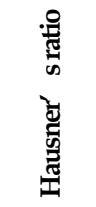 & 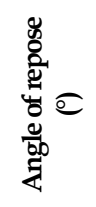 \\
\hline F1 & $\begin{array}{c}0.438 \pm \\
0.002\end{array}$ & $\begin{array}{c}0.503 \pm \\
0.006\end{array}$ & $\begin{array}{l}12.4 \pm \\
0.346\end{array}$ & $\begin{array}{l}1.14 \pm \\
0.046\end{array}$ & $\begin{array}{c}30.60 \pm \\
0.566\end{array}$ \\
\hline F2 & $\begin{array}{c}0.429 \pm \\
0.007\end{array}$ & $\begin{array}{c}0.479 \pm \\
0.009\end{array}$ & $\begin{array}{c}12.65 \pm \\
0.618\end{array}$ & $\begin{array}{l}1.12 \pm \\
0.040\end{array}$ & $\begin{array}{c}30.00 \pm \\
0.173\end{array}$ \\
\hline F3 & $\begin{array}{c}0.477 \pm \\
0.019\end{array}$ & $\begin{array}{c}0.560 \pm \\
0.023\end{array}$ & $\begin{array}{c}14.76 \pm \\
1.721\end{array}$ & $\begin{array}{l}1.17 \pm \\
0.023\end{array}$ & $\begin{array}{c}28.03 \pm \\
0.208\end{array}$ \\
\hline F4 & $\begin{array}{c}0.491 \pm \\
0.010\end{array}$ & $\begin{array}{c}0.551 \pm \\
0.013\end{array}$ & $\begin{array}{c}10.93 \pm \\
0.150\end{array}$ & $\begin{array}{l}1.12 \pm \\
0.003\end{array}$ & $\begin{array}{c}28.30 \pm \\
0.346\end{array}$ \\
\hline F5 & $\begin{array}{c}0.416 \pm \\
0.007\end{array}$ & $\begin{array}{c}0.471 \pm \\
0.009\end{array}$ & $\begin{array}{c}11.74 \pm \\
0.248\end{array}$ & $\begin{array}{l}1.13 \pm \\
0.004\end{array}$ & $\begin{array}{c}27.24 \pm \\
0.295\end{array}$ \\
\hline F6 & $\begin{array}{c}0.412 \pm \\
0.027\end{array}$ & $\begin{array}{c}0.479 \pm \\
0.018\end{array}$ & $\begin{array}{l}14.0 \pm \\
1.212\end{array}$ & $\begin{array}{l}1.16 \pm \\
0.015\end{array}$ & $\begin{array}{c}26.78 \pm \\
0.600\end{array}$ \\
\hline F7 & $\begin{array}{c}0.477 \pm \\
0.010\end{array}$ & $\begin{array}{c}0.556 \pm \\
0.010\end{array}$ & $\begin{array}{c}14.20 \pm \\
0.266\end{array}$ & $\begin{array}{c}1.166 \pm \\
0.004\end{array}$ & $\begin{array}{c}27.77 \pm \\
0.546\end{array}$ \\
\hline F8 & $\begin{array}{c}0.466 \pm \\
0.003\end{array}$ & $\begin{array}{c}0.541 \pm \\
0.001\end{array}$ & $\begin{array}{c}14.05 \pm \\
0.531\end{array}$ & $\begin{array}{c}1.623 \pm \\
0.064\end{array}$ & $\begin{array}{c}27.29 \pm \\
0.272\end{array}$ \\
\hline F9 & $\begin{array}{c}0.478 \pm \\
0.003\end{array}$ & $\begin{array}{c}0.561 \pm \\
0.001\end{array}$ & $\begin{array}{c}14.76 \pm \\
0.462\end{array}$ & $\begin{array}{l}1.19 \pm \\
0.035\end{array}$ & $\begin{array}{c}27.34 \pm \\
0.140\end{array}$ \\
\hline
\end{tabular}

Post compression results

The tablets were evaluated for weight variation, thickness, hardness, friability drug content, and in vitro drug release profiles. Weight variation data indicates no significant difference in individual tablet weight from the average weight $(500.333 \pm 0.577$ to $502.33 \pm 0.577)$. Tablet hardness was observed within the range of $3.26 \pm 0.115$ to $3.60 \pm 0.200 \mathrm{~kg} / \mathrm{cm}^{2}$. A uniform thickness of the tablets was observed in the range of $3.23 \pm 0.004$ to $3.28 \pm 0.008$. The Friability of all the formulations was below $1 \%$, indicating good mechanical strength of the tablets (Table V). From the in vitro drug release data, it was clear that the drug release was decreased with an increase in polymer concentration. The drug release was found to occur through a swelling process ${ }^{35}$.

Table VI was to find out the mechanism of drug release, and also to verify the fact that whether diffusion was Fickian or non-Fickian. The in vitro dissolution data of all the batches was plotted according to the Peppas' equation, in which cumulative log percentage of drug release was plotted against log time. From the kinetic data, it was evident that the drug release was found to follow Peppas' model for all the formulations, and the release was diffusion controlled. The calculated slope values of Peppas' equations gave a value close to 1 but less than 1 , which confirmed that the release mechanism of aceclofenac from the hollow beads was Fickian diffusion with swelling in both the media ${ }^{36}$. From Table VII, it was clear that all the formulations had ' $n$ ' values greater than 0.5 and less than 1 , which confirms that the release mechanism of aceclofenac from the prepared 
matrix tablets in phosphate buffer was Fickian diffusion with swelling ${ }^{37}$.

Table V. Post compression results of aceclofenac sustained release matrix tablets

\begin{tabular}{|c|c|c|c|c|c|}
\hline 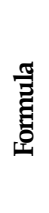 & 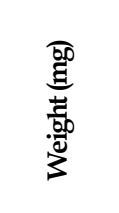 & 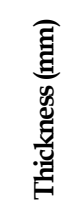 & 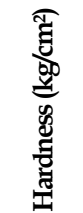 & 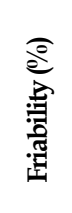 & 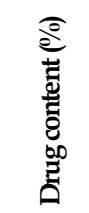 \\
\hline F1 & $\begin{array}{c}501.33 \pm \\
0.577\end{array}$ & $\begin{array}{l}3.23 \pm \\
0.035\end{array}$ & $\begin{array}{l}3.53 \pm \\
0.115\end{array}$ & 0.31 & 97.89 \\
\hline F2 & $\begin{array}{c}501.67 \pm \\
0.535\end{array}$ & $\begin{array}{l}3.26 \pm \\
0.010\end{array}$ & $\begin{array}{l}3.60 \pm \\
0.200\end{array}$ & 0.48 & 100.59 \\
\hline F3 & $\begin{array}{c}500.67 \pm \\
1.528\end{array}$ & $\begin{array}{l}3.25 \pm \\
0.005\end{array}$ & $\begin{array}{l}3.46 \pm \\
0.115\end{array}$ & 0.64 & 96.32 \\
\hline $\mathrm{F} 4$ & $\begin{array}{c}502.33 \pm \\
0.577\end{array}$ & $\begin{array}{l}3.27 \pm \\
0.006\end{array}$ & $\begin{array}{l}3.40 \pm \\
0.200\end{array}$ & 0.71 & 97.99 \\
\hline F5 & $\begin{array}{c}500.68 \pm \\
0.438\end{array}$ & $\begin{array}{l}3.28 \pm \\
0.008\end{array}$ & $\begin{array}{l}3.26 \pm \\
0.115\end{array}$ & 0.33 & 96.32 \\
\hline F6 & $\begin{array}{c}501.33 \pm \\
1.155\end{array}$ & $\begin{array}{l}3.25 \pm \\
0.012\end{array}$ & $\begin{array}{l}3.33 \pm \\
0.120\end{array}$ & 0.47 & 100.11 \\
\hline F7 & $\begin{array}{c}501.23 \pm \\
1.535\end{array}$ & $\begin{array}{l}3.24 \pm \\
0.007\end{array}$ & $\begin{array}{l}3.33 \pm \\
0.115\end{array}$ & 0.63 & 99.15 \\
\hline F8 & $\begin{array}{c}502.33 \pm \\
0.577\end{array}$ & $\begin{array}{l}3.27 \pm \\
0.007\end{array}$ & $\begin{array}{l}3.40 \pm \\
0.200\end{array}$ & 0.68 & 99.14 \\
\hline F9 & $\begin{array}{c}500.33 \pm \\
0.577\end{array}$ & $\begin{array}{l}3.23 \pm \\
0.004\end{array}$ & $\begin{array}{l}3.50 \pm \\
0.115\end{array}$ & 0.65 & 100.11 \\
\hline
\end{tabular}

Table VI. In vitro drug release of aceclofenac from sustained release matrix tablets in phosphate buffer

\begin{tabular}{|c|c|c|c|c|c|c|c|c|c|}
\hline \multirow{2}{*}{$\begin{array}{c}\text { Time } \\
\text { (hours) }\end{array}$} & \multicolumn{9}{|c|}{ Formula } \\
\hline & F1 & F2 & F3 & F4 & F5 & F6 & F7 & F8 & F9 \\
\hline 0 & 0 & 0 & 0 & 0 & 0 & 0 & 0 & 0 & 0 \\
\hline 0.5 & $\begin{array}{l}\text { 点 } \\
\text { 点 } \\
\text { io }\end{array}$ & 贲 & $\begin{array}{l}+1 \\
\text { Sa } \\
\stackrel{\sim}{\infty}\end{array}$ & 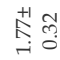 & 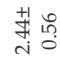 & 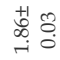 & 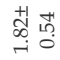 & 封菅。 & 贲 导 \\
\hline 1 & 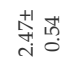 & 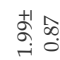 & 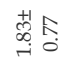 & 苫 & 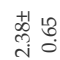 & 萑 & 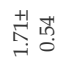 & 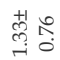 & 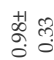 \\
\hline 2 & 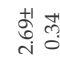 & $\begin{array}{l}+1 \\
\underset{j}{+1}\end{array}$ & 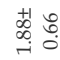 & 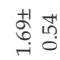 & 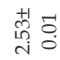 & 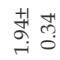 & مُ & 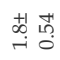 & 萬 \\
\hline 4 & 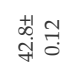 & $\begin{array}{l}+1 \\
\stackrel{7}{7} \\
\text { 융 }\end{array}$ & 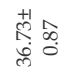 & 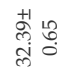 & 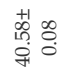 & 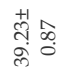 & 䒫 & $\begin{array}{l}\text { त̂ } \\
\text { ते } \\
\text { ले }\end{array}$ & \\
\hline 6 & 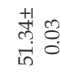 & 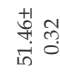 & 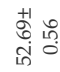 & 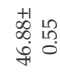 & 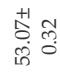 & 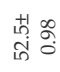 & 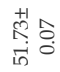 & 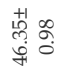 & 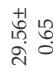 \\
\hline 8 & 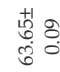 & 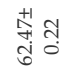 & 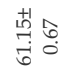 & 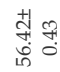 & 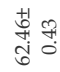 & 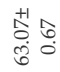 & $\begin{array}{l}+1 \\
\text { क्ष } \\
\text { में }\end{array}$ & 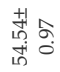 & \\
\hline 10 & 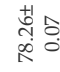 & 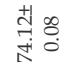 & 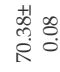 & 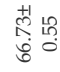 & 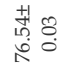 & $\underset{\text { 贲 }}{+}$ & $\begin{array}{l}+1 \\
\stackrel{1}{0} \\
\infty \\
\infty \\
0\end{array}$ & 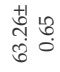 & \\
\hline 12 & 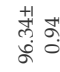 & 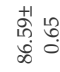 & 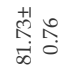 & 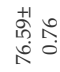 & 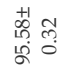 & 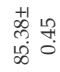 & 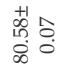 & $\begin{array}{l}\text { N } \\
\text { ते } \\
\text { N }\end{array}$ & 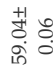 \\
\hline 16 & - & 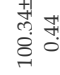 & 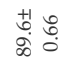 & 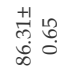 & - & 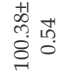 & 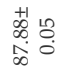 & $\begin{array}{l}\text { 茪 } \\
\text { సे } \\
\infty\end{array}$ & 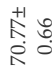 \\
\hline 20 & - & - & 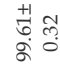 & 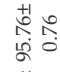 & & - & 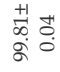 & 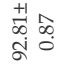 & 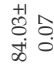 \\
\hline 24 & - & - & - & $\begin{array}{l}+1 \\
\stackrel{7}{8} \\
\end{array}$ & - & - & - & $\begin{array}{l}+1 \\
\vdots \\
0 \\
\sigma_{0}\end{array}$ & 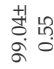 \\
\hline
\end{tabular}

In this work, an attempt was made to formulate and evaluate sustained release matrix tablets of aceclofenac to maintain the plasma drug concentration constant for the whole day. It also helps in decreasing the dosing frequency by which the patient compliance increases. Aceclofenac has a very short half-life ( $\mathrm{t}^{1} / 22-4$ hours), so in conventional tablets, aceclofenac dosing frequency is more. Drugs with a short half-life cannot maintain the plasma drug concentration at the therapeutic levels for a more extended period ${ }^{38}$. Thus, to decrease the dosing frequency and increase patient compliance, sustained release matrix tablets were formulated.

In the preformulation studies, aceclofenac was characterized based on its physicochemical properties by determining melting point, solubility, UV spectroscopy, and FTIR studies. There were no physical changes after, and also no significant interaction of drug with polymers was observed in the UV and FTIR analysis after four weeks as the drug and polymers were compatible and thus were finalized to use in the formulation of sustainedrelease tablets ${ }^{29}$. Quality parameters such as tablet diameter, thickness, hardness, friability, and dissolution profile were evaluated. The best release profile was obtained from tablets containing Guar gum matrix former without HPMC in an equivalent proportion to the drug (F8). The best-selected tablet formulation had friability $0.68 \%$, hardness $3.40 \pm 0.200 \mathrm{~kg} / \mathrm{cm}^{2}$, and $99.8 \pm 0.05$ drug release after 24 hours of the dissolution study.

Table VII. Estimated values of diffusional exponent and correlation coefficient from the dissolution data of aceclofenac in phosphate buffer

\begin{tabular}{|c|c|c|c|c|c|}
\hline \multirow[b]{2}{*}{ Formula } & \multirow{2}{*}{$\begin{array}{c}\text { Zero } \\
\text { order } \\
\left(\mathbf{r}^{2}\right) \\
\end{array}$} & \multirow{2}{*}{$\begin{array}{c}\text { First } \\
\text { order } \\
\left(\mathbf{r}^{2}\right) \\
\end{array}$} & \multirow{2}{*}{$\begin{array}{c}\text { Higuchi's } \\
\text { model } \\
\left(r^{2}\right)\end{array}$} & \multicolumn{2}{|c|}{ Peppas' model } \\
\hline & & & & $\mathbf{r}^{2}$ & $\mathbf{n}$ \\
\hline F1 & 0.9711 & 0.9118 & 0.9973 & 0.9813 & 0.612 \\
\hline $\mathrm{F} 2$ & 0.9709 & 0.8666 & 0.9964 & 0.9674 & 0.598 \\
\hline F3 & 0.9687 & 0.8412 & 0.9959 & 0.9784 & 0.632 \\
\hline F4 & 0.9770 & 0.8204 & 0.9957 & 0.9809 & 0.618 \\
\hline F5 & 0.9771 & 0.8070 & 0.9934 & 0.9712 & 0.545 \\
\hline F6 & 0.9718 & 0.8296 & 0.9950 & 0.9778 & 0.625 \\
\hline F7 & 0.9770 & 0.8066 & 0.9964 & 0.9840 & 0.559 \\
\hline F8 & 0.9696 & 0.8079 & 0.9947 & 0.9824 & 0.573 \\
\hline F9 & 0.9712 & 0.8400 & 0.9978 & 0.9785 & 0.632 \\
\hline
\end{tabular}




\section{CONCLUSION}

In this study, the prepared matrix aceclofenac tablet showed significant drug release property. It maintains the constant concentration for a long time means that it increases the half-life and bioavailability of the drug.

\section{ACKNOWLEDGMENT}

We would acknowledge to Chairman - Mr. B.L. Garg, Secretary - Mr. B.K. Garg and C.E.O. - Mr. C.P. Garg for providing us all the facilities required to complete our work. We also acknowledge faculty members of the department of pharmacy Dr. Alimuddin Saifi, Dr. Bhuwanendra Singh, Mr. Abhishek Chauhan, Mr. Pankaj Jangra, Mr. Nitesh Jangir, and Mrs. Sumita Singh for providing us valuable help during our research work.

\section{AUTHORS' CONTRIBUTION}

All authors made substantial contributions to the conception and design of the study. All authors took responsibility for data analysis, interpretation, and discussion of results. All authors read and approved the final manuscript.

\section{DATA AVAILABILITY}

All data are available from the authors.

\section{CONFLICT OF INTEREST}

There are no conflicts of interest.

\section{REFERENCES}

1. Homayun B, Lin X, Choi HJ. Challenges and Recent Progress in Oral Drug Delivery Systems for Biopharmaceuticals. Pharmaceutics. 2019;11(3):129. doi:10.3390/pharmaceutics11030129

2. Wheless JW, Phelps SJ. A Clinician's Guide to Oral Extended-Release Drug Delivery Systems in
Epilepsy. J Pediatr Pharmacol Ther. 2018;23(4):277-92. doi:10.5863/1551-6776-23.4.277

3. Menditto E, Orlando V, Rosa GD, Minghetti P, Musazzi UM, Cahir C, et al. Patient Centric Pharmaceutical Drug Product Design-The Impact on Medication Adherence. Pharmaceutics. 2020;12(1):44. doi:10.3390/pharmaceutics12010044

4. Laffleur F, Keckeis V. Advances in drug delivery systems: Work in progress still needed? Int J Pharm X. 2020;2:100050. doi:10.1016/j.jpx.2020.100050

5. Tiwari G, Tiwari R, Sriwastawa B, Bhati L, Pandey S, Pandey P, et al. Drug delivery systems: An updated review. Int J Pharm Investig. 2012;2(1):2-11. doi:10.4103/2230-973X.96920

6. Leucuta SE. Drug delivery systems with modified release for systemic and biophase bioavailability. Curr Clin Pharmacol. 2012;7(4):282-317. doi:10.2174/157488412803305786

7. Li J, Mooney DJ. Designing hydrogels for controlled drug delivery. Nat Rev Mater. 2016;1(12):16071. doi:10.1038/natrevmats.2016.71

8. Shah KU, Khan GM. Regulating Drug Release Behavior and Kinetics from Matrix Tablets Based on Fine Particle-Sized Ethyl Cellulose Ether Derivatives: An In Vitro and In Vivo Evaluation. ScientificWorldJournal. 2012;2012:842348. doi:10.1100/2012/842348

9. Rane MM, Bajaj A. Development and optimisation of novel oral formulation of an opioid analgesic using central composite design. Cogent Med. 2017;4(1):1326210. doi:10.1080/2331205X.2017.1326210

10. Eddy AM. Controlled release matrix drug delivery system - A review. Int J Allied Med Sci Clin Res. 2017;5(2):384-98.

11. Trofimiuk M, Wasilewska K, Winnicka K. How to Modify Drug Release in Paediatric Dosage Forms? Novel Technologies and Modern Approaches with Regard to Children's Population. Int J Mol Sci. 2019;20(13):3200. doi:10.3390/ijms20133200

12. Samie M, Bashir S, Abbas J, Khan S, Aman N, Jan H, et al. Design, Formulation and In Vitro Evaluation of Sustained-release Tablet Formulations of Levosulpiride. Turk J Pharm Sci. 2018;15(3):309-18. doi:10.4274/tjps.29200 
13. Iglesias N, Galbis E, Romero-Azogil L, Benito E, Lucas R, García-Martín MG, et al. In-Depth Study into Polymeric Materials in Low-Density Gastroretentive Formulations. Pharmaceutics. 2020;12(7):636. doi:10.3390/pharmaceutics12070636

14. Banerjee A, Verma PRP, Gore S. Controlled Porosity Solubility Modulated Osmotic Pump Tablets of Gliclazide. AAPS PharmSciTech. 2015;16(3):554-68. doi:10.1208/s12249-014-0246-0

15. Zhang X, Xing H, Zhao Y, Ma Z. Pharmaceutical Dispersion Techniques for Dissolution and Bioavailability Enhancement of Poorly Water-Soluble Drugs. Pharmaceutics. 2018;10(3):74. doi:10.3390/pharmaceutics10030074

16. Alkilani AZ, McCrudden MTC, Donnelly RF. Transdermal Drug Delivery: Innovative Pharmaceutical Developments Based on Disruption of the Barrier Properties of the stratum corneum. Pharmaceutics. 2015;7(4):438-70. doi:10.3390/pharmaceutics7040438

17. Nardi-Ricart A, Nofrerias-Roig I, Suñé-Pou M, PérezLozano P, Miñarro-Carmona M, García-Montoya E, et al. Formulation of Sustained Release Hydrophilic Matrix Tablets of Tolcapone with the Application of Sedem Diagram: Influence of Tolcapone's Particle Size on Sustained Release. Pharmaceutics. 2020;12(7):674. doi:10.3390/pharmaceutics12070674

18. Yang JH, Suk KS, Lee BH, Jung WC, Kang YM, Kim $\mathrm{JH}$, et al. Efficacy and Safety of Different Aceclofenac Treatments for Chronic Lower Back Pain: Prospective, Randomized, Single Center, Open-Label Clinical Trials. Yonsei Med J. 2017;58(3):637-43. doi:10.3349/ymj.2017.58.3.637

19. Ricciotti E, FitzGerald GA. Prostaglandins and Inflammation. Arterioscler Thromb Vasc Biol. 2011. 31(5):986-1000. doi:10.1161/ATVBAHA.110.207449

20. Moon YW, Kang SB, Kim TK. Lee MC. Efficacy and Safety of Aceclofenac Controlled Release in Patients with Knee Osteoarthritis: A 4-week, Multicenter, Randomized, Comparative Clinical Study. Knee Surg Relat Res. 2014;26(1):33-42. doi:10.5792/ksrr.2014.26.1.33

21. Meng X, Oh ES, Park MS, Kim D, Kim JH, Kim CO. Comparison of pharmacokinetics and safety of fixeddose combination of SKI306X and aceclofenac versus separate tablets in healthy subjects. Transl Clin Pharmacol. 2017;25(4):196-201.
22. Brogden RN, Wiseman LR. Aceclofenac. A review of its pharmacodynamic properties and therapeutic potential in the treatment of rheumatic disorders and in pain management. Drugs. 1996;52(1):113-24. doi:10.2165/00003495-199652010-00008

23. Rahim H, Sadiq A, Ullah R, Bari A, Amin F, Farooq $\mathrm{U}$, et al. Formulation of Aceclofenac Tablets Using Nanosuspension as Granulating Agent: An Attempt to Enhance Dissolution Rate and Oral Bioavailability. Int J Nanomedicine. 2020;15:8999-9009. doi:10.2147/IJN.S270746

24. Yasmin R, Shoaib MH, Ahmed FR, Qazi F, Ali H, Zafar F. Aceclofenac fast dispersible tablet formulations: Effect of different concentration levels of Avicel PH102 on the compactional, mechanical and drug release characteristics. PLoS One. 2020;15(2):e0223201. doi:10.1371/journal.pone.0223201

25. Mankala SK, Korla AC, Gade S. Development and evaluation of aceclofenac-loaded mucoadhesive microcapsules. J Adv Pharm Technol Res. 2011;2(4):245-54. doi:10.4103/2231-4040.90881

26. Gupta MM, Khoorban A, Ali A, Ramlogan O, Talukdar D. Comparative Quality Control Study of Different Brands of Diclofenac Sodium Tablet Available in Local and Government Pharmacies by In-Vitro Testing. Cureus. 2020;12(11):e11348. doi:10.7759/cureus.11348

27. SolankiSS, Dahima R. Formulation and evaluation of aceclofenac mouth-dissolving tablet. J Adv Pharm Technol Res. 2011;2(2):128-31. doi:10.4103/22314040.82951

28. Ahmed SM, Ali AA, Ali AM, Hassan OA. Design and in vitro/in vivo evaluation of sustained-release floating tablets of itopride hydrochloride. Drug Des Devel Ther. 2016;10:4061-71. doi:10.2147/dddt.s115909

29. Sipos E, Kósa N, Kazsoki A, Szabó ZI, Zelkó R. Formulation and Characterization of AceclofenacLoaded Nanofiber Based Orally Dissolving Webs. Pharmaceutics. 2019;11(8):417. doi:10.3390/pharmaceutics11080417

30. Ding H, Li B, Boiarkina I, Wilson DI, Yu W, Young BR. Effects of Morphology on the Bulk Density of Instant Whole Milk Powder. Foods. 2020;9(8):1024. doi:10.3390/foods9081024 
31. Shah RB, Tawakkul MA, Khan MA. Comparative Evaluation of Flow for Pharmaceutical Powders and Granules. AAPS PharmSciTech. 2008;9(1):250-8. doi:10.1208/s12249-008-9046-8

32. Fu JJ, Chen C, Ferellec JF, Yang J. Effect of Particle Shape on Repose Angle Based on Hopper Flow Test and Discrete Element Method. Adv Civ Eng. 2020;2020:8811063. doi:10.1155/2020/8811063

33. Al-Hashemi HMB, Al-Amoudi OSB. A review on the angle of repose of granular materials. Powder Technol. 2018;330:397-417. doi:10.1016/j.powtec.2018.02.003

34. Jallo LJ, Ghooi C, Gurumurthy L, Patel U, Davé RN. Improvement of flow and bulk density of pharmaceutical powders using surface modification. Int J Pharm. 2012;423(2):213-25. doi:10.1016/j.jpharm.2011.12.012

35. Moin A, Gangadharappa HV, Adnan M, Rizvi SM, AshrafSA, Patel M, et al. Modulation of Drug Release from Natural Polymer Matrices by Response Surface Methodology: in vitro and in vivo Evaluation. Drug Des Devel Ther. 2020;14:5325-36. doi:10.2147/DDDT.S279955

36. Dwivedi R, Singh AK, Dhillon A. pH-responsive drug release from dependal-M loaded polyacrylamide hydrogels. J Sci Adv Mater Dev. 2017;2(1):45-50. doi:10.1016/j.jsamd.2017.02.003

37. Koirala S, Nepal P, Ghimire G, Basnet R, Rawat I, Dahal $\mathrm{A}$, et al. Formulation and evaluation of mucoadhesive buccal tablets of aceclofenac. Heliyon. 2021;7(3):e06439. doi:10.1016/j.heliyon.2021.e06439

38. Dahiya S, Kaushik A, Pathak K. Improved Pharmacokinetics of Aceclofenac Immediate Release Tablets Incorporating its Inclusion Complex with Hydroxypropyl- $\beta$-Cyclodextrin. Sci Pharm. 2015;83(3):501-10. doi:10.3797/scipharm.1509-07 